\title{
The Role of Accounting in the Prevention of Corruption: Perception of Experts from Bosnia and Herzegovina
}

Benina Veledar

Sarajevo School of Economics and Business, Bosnia and Herzegovina

\section{Abstract}

Corruption in the public sector is problem that almost all countries in the world face with, in greater or lesser extent. During couple of past years, Bosnia and Herzegovina has had a constant growth of corruption. According to the Corruption Perception Index, Bosnia and Herzegovina has moved from 72nd position in 2013 to 80th position in 2014 , with scores that had led it nearly to zones with high levels of corruption. Due to the fact that corruption in the public sector discourages innovation and entrepreneurship, and thus leaves extremely harmful effects on the entire economy of the country, at the end of 2013 research was conducted on a sample of 208 public officials and experts in the fields of accounting and auditing. The objective of the research was to determine the extent to which specific accounting tools can contribute to the suppression, or at least reducing, corruption in the public sector of Bosnia and Herzegovina. Research results showed that implementation of the program budgeting and responsibility accounting, through the efficient allocation of scarce budgetary resources between programs and the establishment of public accountability, can help the fight against corruption, improve the business climate and innovations, and thus contribute to the development of the whole country.

Keywords: program budgeting, responsibility accounting, corruption, public sector, innovation, Bosnia and Herzegovina

JEL classification: M41

\section{Introduction}

The public demand for accountability by governments and managers in the public sector requires the reform of the way in which public management carry out their activities. However, despite great pressure from the public and the fact that resources are becoming scarcer, the effect of public sector employees are often not guided by societal, but only their own interests. A special look at this issue gives the Public Choice Theory/ Economy of Public Choice, which explains the behavior of politicians and public servants (Shughart II, 2008). It assumes that people are guided by their own interests, so that the motivation of employees in the public sector is not different from the motivation of all other human beings. Voters are supporting candidates they think will contribute to their well-being, bureaucrats tend to make progress in their careers, and politicians want to keep the position and be reelected. According to Ball (2011) this theory greatly contributes to understanding why the government does not support transparency, or wants someone else to establish standards for financial reporting, and why finance ministers generally do not call for the improvement of budget accounting. On the other hand, citizens and investors deserve a more reliable and higher quality financial information, greater transparency and accountability from the authorities. Without transparency, there is no improvement, trust or responsibility (Hoogervorst, 2011). 
Next theory, which served as a starting point for many studies, is the Public Service Motivation Theory (PSM). It focuses on the impact of the remuneration of employees in the public and private sector on their organizations. One of conducted studies showed that there were differences in motivating employees in the public and private sectors, and that rewarding on the highest levels of public servants had a positive effect on commitment to the organization (Crewson, 1997). Francois (2000) in his research, based on PSM theory, establishes the conditions under which employees in the public administration invest greater efforts in carrying out their duties then employees in companies, whose main objective is the maximization of profit. Based on the same facts Houston (2000) made a comparative analysis of how employees in the private and public sector evaluate internal (intrinsic) or external (extrinsic) rewards. His research has shown that public sector employees valued more internal rewards, e.g. promotion, because it creates a sense of achievement, while employees in the private sector valued more external rewards, e.g. salary raise, reduced working hours. Brewer et al. (2000) with the help of a research technique called $Q$ - methodology investigated the motives of individuals to perform public service. Having examined the motives of 69 individuals, they identified four different concepts of PSM: Samaritans, Communitarians, Patriots and Humanitarians. These four groups of individuals differ in their scope of interest. Samaritans are concerned about other individuals, Communitarians for the community, Patriots for the nation and Humanitarians for the humankind.

There are plenty of studies that deal with the problems that arise when public officials put their own interests above all. It is called a corruption, which means the misuse of public services in order to achieve personal gain. Čubela et al. (2012) claim that the reasons for corruption lie in poverty or greed, excessive regulation and unenforceability of regulations, lack of appropriate supervisory and institutional frameworks, too much discretion rights and a wide range of government activities. Mauro (1998) showed in his research that predatory behavior by corrupt politicians can undermine the composition of public expenditure. The analysis of the sample, which included data from more than 100 countries around the world, showed that the presence of corruption generally has a negative impact on the amount of public funds allocated to education, which has a direct impact on economic growth and development of the country. Anokhin et al. (2009) drew on longitudinal data from sixty-four nations to test the proposition that the level of corruption affects rates of entrepreneurial activity and innovation across nations. Results indicated that there was a positive curvilinear relationship between the control of corruption and three independent measures of entrepreneurial and innovative activity across nations.

Almost all countries around the world face the corruption in the public sector as a problem, in greater or lesser extent. Default mean of measuring the level of perceived corruption among public officials and politicians is the Corruption Perceptions Index - CPI, which serves as a reminder that abuse of power, bribery and covert operations continue to ravage societies around the world. In 2014, Index has rated 175 countries on a scale from 0 (highly corrupt) to 100 (very clean). According to the published results, not one single country has a perfect score, while more than two-thirds score below 50.' This points out a serious problem of corruption at the global level that threatens economic growth for all. Bosnia and Herzegovina has moved from 72nd position in 2013 to 80th position in 2014, with scores that had led nearly to zones with high levels of corruption.

Ihttps://www.transparency.org/cpi2014/results (July $4^{\text {th }}$ 2015) 
Due the fact that corruption in the public sector discourages innovation and entrepreneurship, and thus leaves extremely harmful effects on the entire economy of the country, research was conducted on a sample of 208 public officials and experts in the fields of accounting and auditing at the end of 2013.

Aim of the research is to determine the extent to which specific accounting tools can contribute to the fight against corruption, the improvement of business climate and innovations, and the country development. The hypothesis of the research is that implementation of the program budgeting and responsibility accounting, through the efficient allocation of scarce budgetary resources between programs and the establishment of public accountability, can help the fight against corruption, improve the business climate and innovations, and thus contribute to the development of the whole country. Applied statistical tests confirmed stated hypothesis.

The paper is organized as follows. In Methodology section we describe the main characteristics of the survey as well as the methodology used to perform quantitative analysis. In Results section we present details of the statistical analyses and the results obtained. Discussion and Conclusion section provides brief discussion of the conducted research, notes its limitations and proposes further research directions.

\section{Methodology}

In order to achieve the objectives of the paper and examine stated hypothesis, the survey was carried out among employees within budget organizations from Bosnia and Herzegovina.

Table 1

Demographic characteristics

\begin{tabular}{|l|r|r|}
\hline \multicolumn{3}{|c|}{ Number of respondents (N=208) } \\
\hline Age & 3 & \% \\
\hline Under 25 years & 52 & 1,44 \\
\hline From 26 to 35 years & 42 & 25 \\
\hline From 36 to 45 years & 73 & 35,19 \\
\hline From 46 to 55 years & 38 & 18,27 \\
\hline 56 years and more & 74 & 35,58 \\
\hline Gender & 734 & 64,42 \\
\hline Male & \multicolumn{3}{|r|}{} \\
\hline Female & 8 & 3,85 \\
\hline Educational level & 173 & 83,17 \\
\hline High School & 27 & 12,98 \\
\hline Bachelor & \multicolumn{3}{|r|}{} \\
\hline MSc, PhD & 49 & 23,56 \\
\hline Work position & 25 & 12,02 \\
\hline Accountants & 79 & 37,98 \\
\hline Auditors & 14 & 6,73 \\
\hline Finance officers & 18 & 8,65 \\
\hline Managers & 23 & 11,06 \\
\hline Faculty members
\end{tabular}

Source: Author's research; December 2013 
Target population consisted of two groups: (i) public servants at the municipal level (136 municipalities in B\&H), Canton level (10 cantons), the Federal level (16 ministries) and State level $(9$ ministries); (ii) experts in accounting and auditing profession in B\&H. Participants were contacted by e-mail and/or phone and asked to fulfill the questionnaire. Out of 400 sent e-mails, we received 208 valid answers. Table 1 and 2 show sample characteristics.

Table 2

Institutional characteristics

\begin{tabular}{|c|c|c|}
\hline & Number of respondents $(\mathrm{N}=\mathbf{2 0 8})$ & $\%$ \\
\hline \multicolumn{3}{|c|}{ Number of employees within organization } \\
\hline Under 50 employees & 70 & 33,65 \\
\hline From 51 to 250 employees & 113 & 54,33 \\
\hline More than 250 employees & 25 & 12,02 \\
\hline \multicolumn{3}{|l|}{ Type of budget organization } \\
\hline Public institution & 76 & 36,54 \\
\hline Government administration & 132 & 63,46 \\
\hline \multicolumn{3}{|c|}{ Administrative level of budget organization } \\
\hline State & 22 & 10,58 \\
\hline Entity & 62 & 29,81 \\
\hline Cantonal & 45 & 21,63 \\
\hline Municipal & 78 & 37,50 \\
\hline Other & 1 & 0,48 \\
\hline
\end{tabular}

Source: Author's research; December 2013

For the presentation of research results, we used the following methods of descriptive statistics: distribution of absolute and relative frequency, cumulative relative frequency, mean value, standard deviation and selected graphical representations. To test the stated hypothesis, we used the following statistical methods: t-test on the assumed value of the average value of the population using the bootstrap option, using 1,000 sub-samples, as well as Spearman's rank correlation and regression analysis. Respondents' attitudes on issues that reflect the objective of research were derived using a Likert scale. Statistical analysis was performed using the SPSS statistical software version 16.0.

\section{Results}

Table 3 shows the average scores related to attitudes of respondents about the issue Effective measures for the allocation of budgetary resources between programs. The highest average grade has a question regarding the allocation of the necessary funds to the budget users in accordance with the selected programs (4.58), and the lowest average grade has a question related to the preparation of the program budget for the next fiscal year (4.36). It is important to emphasize that all measures received extremely high ratings, which in any case are not less than the average score of 4.0 . 


\section{Table 3}

Descriptive statistics of stakeholder views on the effectiveness of specific measures for the allocation of budgetary resources between programs

\begin{tabular}{|l|r|r|r|r|r|}
\hline & \multicolumn{1}{|c|}{ N } & \multicolumn{1}{|c|}{ Min } & \multicolumn{1}{|c|}{ Max } & \multicolumn{1}{|c|}{ Average } & St.Dev. \\
\hline $\begin{array}{l}\text { Establishing strategic and operational } \\
\text { objectives by budget users }\end{array}$ & 208 & 1 & 5 & 4,500 & 0,722 \\
\hline $\begin{array}{l}\text { Defining programs aimed at achieving the } \\
\text { strategic and operational goals }\end{array}$ & 208 & 2 & 5 & 4,438 & 0,726 \\
\hline $\begin{array}{l}\text { Allocation of the necessary funds to the } \\
\text { budget users in accordance with the } \\
\text { selected programs }\end{array}$ & 206 & 1 & 5 & 4,539 & 0,730 \\
\hline $\begin{array}{l}\text { Determination of the responsibility chain for } \\
\text { the implementation of programs }\end{array}$ & 207 & 2 & 5 & 4,585 & 0,669 \\
\hline $\begin{array}{l}\text { Performance measurement of the programs } \\
\text { in order to determine the extent to which } \\
\text { they achieved strategic and operational } \\
\text { objectives. }\end{array}$ & 207 & 2 & 5 & 4,531 & 0,659 \\
\hline $\begin{array}{l}\text { Abolition, reduction or modification of the } \\
\text { program if it: (i) does not achieve the set } \\
\text { goals or (ii) achieve the set goals with } \\
\text { unreasonable costs }\end{array}$ & 208 & 2 & 5 & 4,437 & 0,796 \\
\hline $\begin{array}{l}\text { Preparation of the program budget for the } \\
\text { next fiscal year }\end{array}$ & 208 & 2 & 5 & 4,558 & 0,642 \\
\hline $\begin{array}{l}\text { Preparation of the program budget for the } \\
\text { next three fiscal years }\end{array}$ & 208 & 1 & 5 & 4,361 & 0,834 \\
\hline
\end{tabular}

Source: Author's research; December 2013

\section{Table 4}

Descriptive statistics of stakeholder views on the effectiveness of specific measures for the establishment of public accountability

\begin{tabular}{|l|r|r|r|r|r|}
\hline & \multicolumn{1}{|c|}{ N } & \multicolumn{1}{|c|}{ Min } & \multicolumn{1}{|c|}{ Max } & \multicolumn{1}{|c|}{ Average } & St.Dev. \\
\hline $\begin{array}{l}\text { Establishing strategic and operational objectives } \\
\text { by budget users }\end{array}$ & 208 & 1 & 5 & 4,370 & 0,805 \\
\hline $\begin{array}{l}\text { Defining programs aimed at achieving the } \\
\text { strategic and operational goals }\end{array}$ & \multicolumn{1}{|c|}{208} & 1 & 5 & 4,370 & 0,763 \\
\hline $\begin{array}{l}\text { Allocation of the necessary funds to the budget } \\
\text { users in accordance with the selected programs }\end{array}$ & 208 & 1 & 5 & 4,480 & 0,695 \\
\hline $\begin{array}{l}\text { Determination of the responsibility chain for the } \\
\text { implementation of programs }\end{array}$ & 208 & 2 & 5 & 4,540 & 0,728 \\
\hline $\begin{array}{l}\text { Performance measurement of the programs in } \\
\text { order to determine the extent to which they } \\
\text { achieved strategic and operational objectives. }\end{array}$ & 208 & 2 & 5 & 4,490 & 0,742 \\
\hline $\begin{array}{l}\text { Abolition, reduction or modification of the } \\
\text { program if it: (i) does not achieve the set goals or } \\
\text { (ii) achieve the set goals with unreasonable costs }\end{array}$ & 208 & 2 & 5 & 4,390 & 0,791 \\
\hline $\begin{array}{l}\text { Preparation of the program budget for the next } \\
\text { fiscal year }\end{array}$ & 208 & 2 & 5 & 4,400 & 0,742 \\
\hline $\begin{array}{l}\text { Preparation of the program budget for the next } \\
\text { three fiscal years }\end{array}$ & 207 & 2 & 5 & 4,240 & 0,876 \\
\hline
\end{tabular}

Source: Author's research; December 2013 
Table 4 shows the average score related to the attitudes of respondents about the issue Effectiveness of measures for the establishment of public accountability. The highest average grade received a question regarding the allocation of the necessary funds to the budget users in accordance with the selected programs $(4,540)$, and the lowest average grade has a question related to the preparation of the program budget for the next fiscal year $(4,240)$.

Table 5 presents the views of respondents about the statement: Application of the program budgeting and responsibility accounting, through the efficient allocation of scarce budgetary resources between programs and the establishment of public accountability, can help the fight against corruption, improve the business climate and innovations, and thus contribute to the development of the whole country. Of all respondents, the largest share $(93.75 \%)$ agreed with this statement, and a very small number (6.25\%) expressed their disapproval.

\section{Table 5}

The views of respondents about the statement: Application of the program budgeting and responsibility accounting, through the efficient allocation of scarce budgetary resources between programs and the establishment of public accountability, can help the fight against corruption, improve the business climate and innovations, and thus contribute to the development of the whole country

\begin{tabular}{|l|r|r|r|}
\hline Respondents' attitude & Number of respondents & Structure in \% & \multicolumn{1}{c|}{ Cumulative \% } \\
\hline Agree & 195 & 93,75 & 93,75 \\
\hline Disagree & 13 & 6,25 & 100,00 \\
\hline Total & 208 & 100,00 & \\
\hline
\end{tabular}

Source: Author's research; December 2013

The estimation of the respondents that the application of program budgeting and responsibility accounting can contribute to the development of the country and help fight against corruption was used as a dependent variable. A "backward" linear multiple regression was applied, where all the variables, which measured respondents' perceptions on the implementation of program budgeting and responsibility accounting as effective measures for the allocation of budgetary resources between programs and for the establishment of public responsibility, were used as the independent variables. Table 6 represents the independent variables selected as significant by using "backward" regression in relation to their impact on the dependent variable. It is noticed that variations in estimates of the respondents that the application of program budgeting and responsibility accounting can help the fight against corruption, improve the business climate and innovations, and thus contribute to the development of the whole country, can be best explained by the variables describing the role of implementing program budgeting and responsibility accounting as effective measures for the allocation of public resources between programs and for the establishment of public accountability. 


\section{Table 6}

Regression analysis; Dependent variable: the estimation of the respondents that the application of program budgeting and responsibility accounting can help the fight against corruption, improve the business climate and innovations, and thus contribute to the development of the whole country

\begin{tabular}{|c|c|c|c|c|}
\hline $\begin{array}{l}\text { Groups of } \\
\text { variables }\end{array}$ & Independent variables & $\begin{array}{l}\text { Estimates of } \\
\text { regression } \\
\text { coefficients }\end{array}$ & St. error & P-val. \\
\hline \multicolumn{2}{|l|}{ Constant } & 1,160 & 9,082 & 0,000 \\
\hline \multirow{3}{*}{$\begin{array}{l}\text { Effective } \\
\text { measures for } \\
\text { the allocation } \\
\text { of public } \\
\text { resources } \\
\text { between } \\
\text { programs }\end{array}$} & $\begin{array}{l}\text { Allocation of the necessary funds to the } \\
\text { budget users in accordance with the } \\
\text { selected programs }\end{array}$ & $-0,092$ & $-2,860$ & 0,005 \\
\hline & $\begin{array}{l}\text { Abolition, reduction or modification of } \\
\text { the program if it: (i) does not achieve } \\
\text { the set goals or (ii) achieve the set } \\
\text { goals with unreasonable costs }\end{array}$ & 0,071 & 2,828 & 0,005 \\
\hline & $\begin{array}{l}\text { Preparation of the program budget for } \\
\text { the next three fiscal years }\end{array}$ & $-0,099$ & $-3,050$ & 0,003 \\
\hline \multirow{3}{*}{$\begin{array}{l}\text { Effectiveness of } \\
\text { measures for } \\
\text { the } \\
\text { establishment } \\
\text { of public } \\
\text { accountability }\end{array}$} & $\begin{array}{l}\text { Allocation of the necessary funds to the } \\
\text { budget users in accordance with the } \\
\text { selected programs }\end{array}$ & 0,088 & 2,508 & 0,013 \\
\hline & $\begin{array}{l}\text { Preparation of the program budget for } \\
\text { the next fiscal year }\end{array}$ & $-0,082$ & $-2,072$ & 0,040 \\
\hline & $\begin{array}{l}\text { Preparation of the program budget for } \\
\text { the next three fiscal years }\end{array}$ & 0,096 & 2,347 & 0,020 \\
\hline \multicolumn{2}{|c|}{ Coefficient of determination } & & &, 119 \\
\hline \multicolumn{2}{|c|}{ Adjusted coefficient of determination } & & &, 092 \\
\hline
\end{tabular}

Note: *** statistical significant with $1 \%$ of probability

Source: Author's research; December 2013

\section{Discussion and Conclusion}

At a time of financial crisis, an effective policy to combat corruption and spread the ethics becomes more important than ever. Corruption not only undermines the basic principles of good governance and citizens' trust in the public service, but also has a negative impact on economic growth and competitiveness. In the past few years, different actions were initiated to combat corruption around the world, which included a number of governments, international organizations and prominent individuals. The United Nations are one of the main supporters of the fight against corruption, which adopted a Convention against Corruption in 2004, then the Organization for Economic Cooperation and Development and the World Bank.

According to them, important elements for the establishment of open and transparent public service with integrity are: (i) the development of preventive and corrective instruments, and (ii) the application of these instruments in the daily public management. Looking at this problem from the accounting point of view, we decided to determine the extent to which specific accounting tools can contribute to the suppression, or at least reduction of corruption in the public sector of Bosnia and Herzegovina. Research results showed that implementation of the program budgeting and responsibility accounting, through the efficient allocation of scarce budgetary resources between programs and the establishment of public accountability, can help the fight against corruption, improve the business climate and innovations, and thus contribute to the development of the whole country. 
One of the limitations of the research is primary focus on the budget organizations, which represent the biggest, but not the only component of the public sector. Public and private companies have been omitted from the analysis despite the fact that they can be sources of corruption. Therefore, conducted research can serve as a basis for similar researches aimed at finding adequate accounting tools to control corruption within the public and private companies in $\mathrm{B} \& \mathrm{H}$. It would be interesting to carry out similar researches in neighboring countries.

\section{References}

1. Anokhin, S., Schulze, W.S. (2009), "Entrepreneurship, innovation, and corruption", Journal of Business Venturing, Vol. 24, pp. 465-476.

2. Ball, I. (2011), "Trust and Accountability in Public Financial Management", paper presented at CIPFA's 1st International Conference, 17 March 2011, London.

3. Brewer, G., Selden, S., Facer, R. (2000), "Individual conception of Public Service Motivation", Public Administration Review, Vol. 60 No. 3, pp. 254-264.

4. Crewson, P. (1997), "Public Service Motivation: Building empirical evidence of Incidence and Effect", Journal of Public Administration Research and Theory, Vol. 7 No. 4, pp. 499518.

5. Čubela, S., Rička, Ž. (2012), „Korupcija, kočnica u napretku javnih” [Corruption, brake in public procurement progress], Porezni savjetnik, Vol. 10, pp. 97-101.

6. Francois, P. (2000), "Public service motivation as an argument for government provision", Journal of Public Economics, Vol. 78, pp. 275-299.

7. Hoogervorst, H. (2011), "The objectives of Financial Reporting", presented at European Commission Conference: Financial Reporting and Auditing - A time for change?, February 2011, $9^{\text {th }}$ Brisel, available at: http://ec.europa.eu/internal market/accounting/docs/conference20110209/speech ho ogervorst_en.pdf (accessed July 26th 2014).

8. Houston, D. (2000), "Public service motivation: A multivariate test", Journal of Public Administration Research and Theory, Vol.10 No. 4, pp. 713-727.

9. Mauro, P. (1998), "Corruption and the composition of government expenditure", Journal of Public Economics, Vol. 69, pp. 263-279.

10. Shughart II, W.F. (2008), "Public choice", in Henderson, D.R. (ed.), The Concise Encyclopedia of Economics, Liberty Fund, Indianapolis, pp. 427-430.

11. Transparency International (2014), "Corruption Perceptions Index 2014" available at: https://www.transparency.org/cpi2014/results (accessed July $4^{\text {th }} 2015$ ).

\section{About the author}

Benina Veledar is a PhD candidate and Senior Teaching Assistant at School of Economics and Business, University of Sarajevo, Bosnia and Herzegovina. Main research interests are Cost and Management Accounting, Budget Accounting, Financial Reporting, Financial Reports Analysis and Performance measurement in public sector. Author can be contacted at benina.veledar@efsa.unsa.ba 